\title{
Socio Economic Characteristics of Self Help Group Tribal Women in Nilgiris District, India
}

\author{
T.N. Sujeetha ${ }^{1^{*}}$, M. Anamica ${ }^{1}$ and M. Balarubini ${ }^{2}$ \\ ${ }^{1}$ Department of AE\&RS, TNAU, Tamil Nadu, India \\ ${ }^{2}$ CARDS, TNAU, Tamil Nadu, India \\ *Corresponding author
}

\section{A B S T R A C T}

\begin{tabular}{|c|c|}
\hline & \multirow{6}{*}{$\begin{array}{l}\text { A study was taken up among the tribal women in the Nilgiris district mainly to assess the } \\
\text { determinants of tribal women SHG members for joining SHGs. Kotagiri and Gudalur } \\
\text { blocks were selected based on the presence of NGOs specifically working for the tribes. } \\
\text { Totally twelve SHGs have been randomly selected for the study. This comprises four each } \\
\text { from Todas, Kattunayakas and Paniyas. A sample of } 10 \text { members from each SHGs have } \\
\text { been randomly selected. Thus the total sample size is } 120 \text {. The study reveals that } 38.33 \text { per } \\
\text { cent of the tribal women have low level credit orientation. Majority }(75.83 \%) \text { of the tribal } \\
\text { women are found consulting with spouse and elders for making decisions at all levels } \\
\text { followed by consulting with their family members. Majority }(40.83 \%) \text { of the tribal women } \\
\text { have low level of socio-cultural linkage. Majority ( } 40.83 \%) \text { of the tribal women, exhibited } \\
\text { a low level of intra-tribal communication. Majority }(40.83 \%) \text { of the tribal women } \\
\text { possessed low leadership abilities. More than half }(54.16 \%) \text { of the tribal women were } \\
\text { found to have a low level of entrepreneurial self-efficacy, } 65.00 \text { per cent of the tribal } \\
\text { women in the total sample were found to have low pre-entrepreneurial exposure. Majority } \\
\text { ( } 85.00 \%) \text { of the tribal women are well aware of the Integrated Tribal Development } \\
\text { Programmes. }\end{array}$} \\
\hline & \\
\hline & \\
\hline Articl & \\
\hline & \\
\hline & \\
\hline
\end{tabular}

\section{Introduction}

In recent years, SHGs have become significant institutions for tribal development. It is now being increasingly realized that instead of targeting the individual in the process of development, it would be more useful to adopt the approach of group development (Wilson, 2007).

The group approach makes available the collective wisdom and combined resources for any task. With this background, a critical study of the evaluation of the socio economic characteristics of the Nilgiris tribal women
Self Help Group members have been carried out.

\section{Materials and Methods}

Nilgiris district of Tamil Nadu was purposively selected because it is one of the districts where the percentage of tribal population is higher and the tribal SHGs are actively functioning. Kotagiri and Gudalur blocks were selected based on the presence of NGOs specifically working for the tribes. Among these NGOs, NAWA (Nilgiris 
Adivasi Welfare Association) of Kotagiri block and CTRD (Centre for Tribal and Rural Development Trust) of Gudalur block were purposively selected because both the NGOs strive for the upliftment of the tribal communities viz., Paniyas, Kattunayakars, Todas, Irulas, Kotas and Kurumbas. Among these tribal communities, Todas, Kattunayakas and Paniyas were selected since these communities have more number of women SHGs engaged in the entrepreneurial activities.

Based on this, a sample of eight SHGs and four SHGs from CTRD and NAWA respectively were selected. A sample of ten members from each SHG was considered for the study. From these twelve SHGs, a sample of 120 members was considered as respondents for the study.

\section{Results and Discussion}

The socio economic characteristics of tribal women Self Help Group members are given in Table 1.

\section{Credit orientation}

Credit orientation decides the degree of orientation to avail credit from credit institutions. The overall analysis reveals that 38.33 per cent of the tribal women have low level credit orientation. The reason behind this is that the tribal women feel that credit makes them fall easy victim to local money lenders and leads them to be dependent on them.

\section{Decision making behaviour}

For any activity, decision making is pivotal. The extent to which a woman is able to take independent decision is a measure of her empowerment. Among the total respondents, majority $(75.83 \%)$ of the tribal women are found consulting with spouse and elders for making decisions at all levels followed by consulting with their family members.

\section{Socio-cultural linkage}

From the above table, the overall inference infers that majority $(40.83 \%)$ of the tribal women have low level of socio-cultural linkage. This could be possible as the tribal women are more of traditional in nature with more of conservative behaviour and their linkage outside their social system would also tend to be low.

\section{Intra-tribal communication}

It refers to all such activities performed the tribes to share their ideas and experiences with regard to their economic prosperity. With respect to the total sample, majority $(40.83 \%)$ of the tribal women, exhibited a low level of intra-tribal communication.

\section{Leadership abilities}

Leadership ability refers to ability of a person to influence people to co-operate in achieving a goal. With respect to all the three communities, majority $(40.83 \%)$ of the tribal women possessed low leadership abilities.

\section{Entrepreneurial self-efficacy}

Entrepreneurial self-efficacy is the dynamic set of beliefs about one's capacity to start a new venture and succeed in carrying it out. Table 1 reveals that more than half $(54.16 \%)$ of the tribal women were found to have a low level of entrepreneurial self-efficacy followed by medium and high levels.

\section{Pre entrepreneurial exposure}

Table 1 reveals that 65.00 per cent of the tribal women in the total sample were found to have low pre-entrepreneurial exposure followed by high and medium levels. 
Table.1 Distribution of respondents based on the socio economic characteristics of tribal women SHG members

\begin{tabular}{|c|c|c|c|c|}
\hline \multirow[t]{2}{*}{ S. No. } & \multirow{2}{*}{$\begin{array}{c}\text { Profile of } \\
\text { respondents }\end{array}$} & \multirow[t]{2}{*}{ Category } & \multicolumn{2}{|c|}{ Total $(n=120)$} \\
\hline & & & No & $\%$ \\
\hline \multirow[t]{3}{*}{1.} & \multirow[t]{3}{*}{ Credit orientation } & Low & 46 & 38.33 \\
\hline & & Moderate & 40 & 33.33 \\
\hline & & High & 34 & 28.34 \\
\hline \multirow[t]{5}{*}{2.} & \multirow{5}{*}{$\begin{array}{l}\text { Decision making } \\
\text { behaviour }\end{array}$} & Self without consulting & 7 & 5.83 \\
\hline & & Consulting with Spouse/elders & 91 & 75.83 \\
\hline & & Consulting all the family members & 22 & 18.34 \\
\hline & & Others help in taking decisions & - & - \\
\hline & & No participation & - & - \\
\hline \multirow[t]{3}{*}{3.} & \multirow{3}{*}{$\begin{array}{l}\text { Socio-cultural } \\
\text { linkage }\end{array}$} & Low & 49 & 40.83 \\
\hline & & Moderate & 43 & 35.83 \\
\hline & & High & 28 & 23.34 \\
\hline \multirow[t]{3}{*}{4.} & \multirow{3}{*}{$\begin{array}{l}\text { Intra-tribal } \\
\text { communication }\end{array}$} & Low & 49 & 40.83 \\
\hline & & Moderate & 43 & 35.83 \\
\hline & & High & 28 & 23.34 \\
\hline \multirow[t]{3}{*}{5.} & \multirow{3}{*}{$\begin{array}{l}\text { Leadership } \\
\text { abilities }\end{array}$} & Low & 49 & 40.83 \\
\hline & & Moderate & 42 & 35.00 \\
\hline & & High & 29 & 24.17 \\
\hline \multirow[t]{3}{*}{6.} & \multirow{3}{*}{$\begin{array}{l}\text { Entrepreneurial } \\
\text { self-efficacy }\end{array}$} & Low & 65 & 54.16 \\
\hline & & Moderate & 31 & 25.84 \\
\hline & & High & 24 & 20.00 \\
\hline \multirow[t]{3}{*}{7.} & \multirow{3}{*}{$\begin{array}{l}\text { Pre } \\
\text { entrepreneurial } \\
\text { exposure }\end{array}$} & Low & 78 & 65.00 \\
\hline & & Moderate & 16 & 13.33 \\
\hline & & High & 26 & 21.67 \\
\hline \multirow[t]{8}{*}{8.} & \multirow{8}{*}{$\begin{array}{l}\text { Awareness on } \\
\text { tribal } \\
\text { developmental } \\
\text { programmes }\end{array}$} & Horticulture department & 95 & 79.17 \\
\hline & & Hill Area Development Programme & 90 & 75.00 \\
\hline & & Scheme for Tea planting for tribal farmers & 90 & 75.00 \\
\hline & & Tamil Nadu Government Insurance Scheme & 64 & 53.33 \\
\hline & & Forest Rights Act & 90 & 75.00 \\
\hline & & Integrated Child Development Programme & 61 & 50.83 \\
\hline & & Health Education Programmes & 100 & 83.33 \\
\hline & & Integrated Tribal Development Programme & 102 & 85.00 \\
\hline
\end{tabular}

\section{Awareness on tribal developmental programmes}

From the above table it could be inferred that from the total sample point of view, majority $(85.00 \%)$ of the tribal women are well aware of the Integrated Tribal Development Programmes.
The tribal women have become well secured in their livelihood status due to their participation in Self Help Groups. If every effort taken results in the expected positive ways, the tribal women could visualize and experience the better side of their lives. This has been proved in the study. Once after the introduction of Self Help Groups, the tribal 
women have begun to actively participate in all spheres of social activities.

\section{References}

Anyanwu, C. M. 2004. Microfinance Institutions in Nigeria: Policy, Practice and Potential, Paper Presented at the G24 Workshop on "Constraints to Growth in Sub Saharan Africa," Pretoria, South Africa, Nov. 29-30.
Singh, Kavaljit, Banking Sector Liberalization in India: Some Distributing Trends, ASED, August 29, 2005.

Wilson, F., J. Kickul and D. Marlino. 2007. Gender, Entrepreneurial Self-Efficacy, and Entrepreneurial Career Intentions: Implications for Entrepreneurship Education. Entrepreneurship Theory and Practice, 31(3): 387-406.

\section{How to cite this article:}

Sujeetha, T.N., M. Anamica and Balarubini, M. 2017. Socio Economic Characteristics of Self Help Group Tribal Women in Nilgiris District, India. Int.J.Curr.Microbiol.App.Sci. 6(11): 3988-3991. doi: https://doi.org/10.20546/ijcmas.2017.611.467 